\title{
IGNEOUS STRUCTURES AND TEXTURES IN THE MAJORQAP QÂVA OUTCROP OF THE FISKENESSET ANORTHOSITE COMPLEX
}

\author{
J. S. Myers
}

Primary structures and textures are extensively preserved in the large Majorqap qâva outcrop of the early Precambrian basic igneous complex of Fiskenæsset. The outcrop is situated on the northern side of the head of Fiskenasfjorden $\left(63^{\circ} 16^{\prime} \mathrm{N} ; 50^{\circ} 05^{\prime} \mathrm{W}\right)$ and is sub-rectangular in outline, 7 kilometres long and 5 kilometres wide (plate 1). Its form is basin-shaped and a section of 1000 metres is exposed through it from the summit of Majorqap qâva to the floor of a narrow valley which cuts diagonally across the outcrop (plate 2 ).

The outline of the Majorqap qâva outcrop was delineated by Peter Appel prospecting for Platinomino A/S in 1970, and the author started to map it in 1971 as part of the GGU programme of detailed systematic mapping of the region. Only the western half of the outcrop has so far been mapped, based on 18 days fieldwork, but it is clear that, because of the variety and degree of preservation of primary structures, it provides much better evidence of the primary nature of the meta-igneous Fiskenæsset complex than any of the smaller and more deformed outcrops investigated hitherto (Ghisler \& Windley, 1967; Windley, 1971; and Windley et al., in press).

The basic igneous rocks of the Majorqap qâva outcrop have been repeatedly deformed and metamorphosed but primary igneous textures and structures are extensively preserved in a little-deformed state and show that the rocks can be divided into two major groups: a layered series and an anorthosite unit.

The rocks of the layered series (plate 2) are coarse grained and can be subdivided in the field into primary mafitites, gabbros and leuco-gabbros based on the percentage of mafic minerals per unit volume (following the parameters suggested by Streckeisen, 1967). Primary mela-gabbros and anorthosites also form minor components of the layered series. The leuco-gabbros are similar to rocks which in Greenland have previously been called gabbro-anorthosites (after Berthelsen, 1957) and for which Windley (1971) and Windley et al. (in press) have proposed the inappropriate name "ophitic gabbro".

The layered series is made up of three main units which are, in primary upward sequence: 


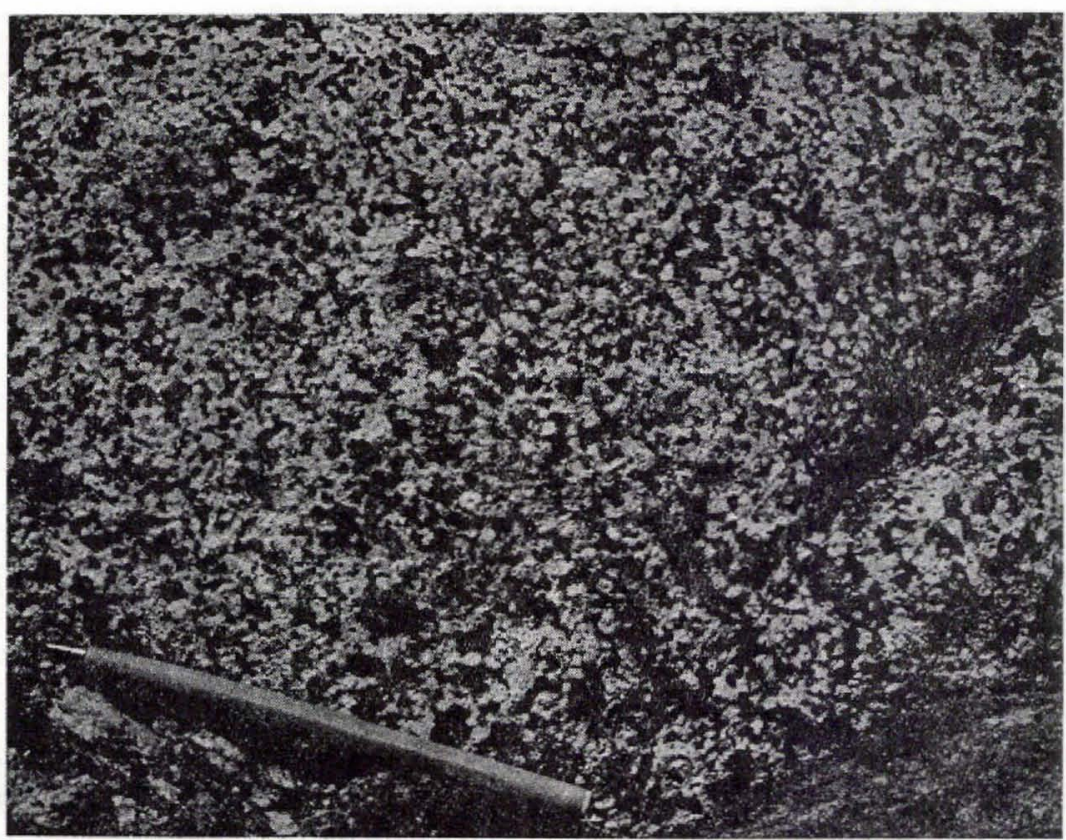

Fig. 11 Relatively fine grained meta-leucogabbro (plagioclase cumulate) with an undeformed igneous texture. Meta-leucogabbro with this primary grain size generally forms only the lowest 10 metres of the layered series and probably represents a primary fine grained bottom horizon of the intrusion. The minerals are plagioclase and green hornblende and the biro is $13 \mathrm{~cm}$ long. Typical of the bottom of the lower leucogabbro unit of the layered series.

1. A lower leuco-gabbro unit (20-40 metres thick), composed of leuco-gabbro with relict equant plagioclase primocrysts either of uniform size between 1 and 5 millimetres in diameter (fig. 11) or of a variety of different sizes up to 2 centimetres in diameter.

2. A gabbro unit (40-80 metres thick), composed of gabbro with a few thin mafitite layers.

3. An upper leuco-gabbro unit (200-1000 metres thick), composed of leucogabbro with relict equant plagioclase primocrysts between 2 and 10 centimetres in diameter (fig. 12).

Metamorphosed leuco-gabbros with generally $20-25 \%$ by volume of mafic minerals are the main rock type of the western half of the Majorqap qâva outcrop. Typically they possess a relict cumulate texture made up of relict equidimensional plagioclase primocrysts with interstitial hornblende and lesser amounts of biotite, chromite and pyroxene. The plagioclase primocrysts have generally been replaced by polygonal mosaics of metamorphic plagioclase crystals less than 2 millimetres in diameter (fig. 12) but in many places they have only suffered 


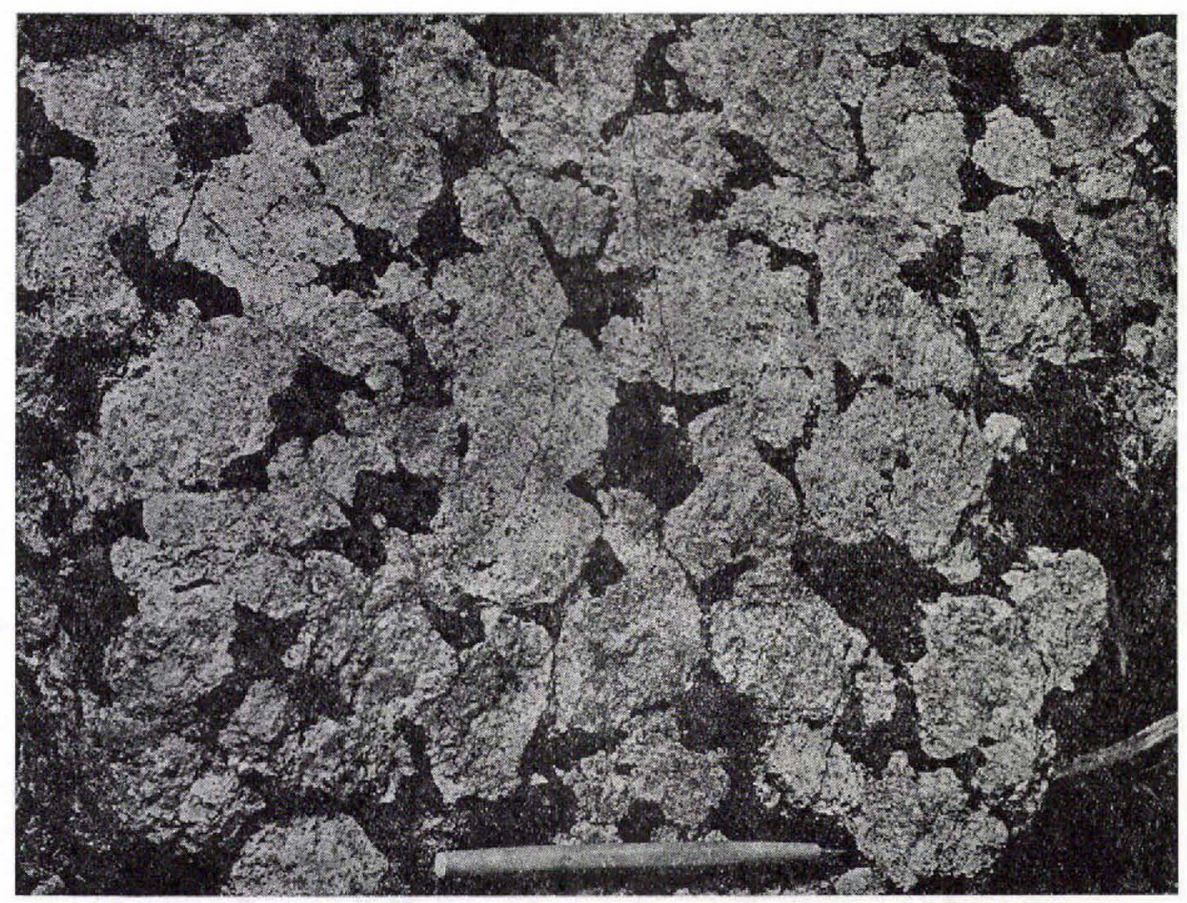

Fig. 12 Relatively medium grained, meta-leucogabbro (plagioclase cumulate) with an undeformed igneous texture. The plagioclase primocrysts have almost entirely been replaced by a polygonal mosaic of finer grained metamorphic plagioclase. The interstitial mafic mineral is green hornblende. The upper leucogabbro unit of the layered series.

partial recrystallisation and large single crystals have survived with thin metamorphic rims. In the field, the interstitial hornblende, biotite and pyroxene appear to be metamorphic and so it is not clear whether they are derived from cumulus or intercumulus minerals. Similarily, although the chromite may represent a cumulus phase and in many cases has survived as primocrysts (cf. Ghisler, 1970), it is too fine grained for this to be identified in the field.

In general, at any one place in the upper leuco-gabbro unit, the size of the plagioclase primocrysts and relict primocrysts is uniform and changes in grain size are gradational on a scale larger than can be viewed from ground level in the field. In the lower leuco-gabbro unit a variety of generally fine grain sizes of plagioclase primocrysts occur together and in a few places grading in the size of primocrysts occurs which shows that the larger cumulus plagioclase crystals sank relative to the smaller ones. In some places in both the lower and upper leuco-gabbro units, the rocks possess a layering shown by variations in the proportions of interstitial mafic minerals. Chromite is of widespread but sporadic occurrence with olive-green spinel, hornblende, biotite and pyroxene between the 


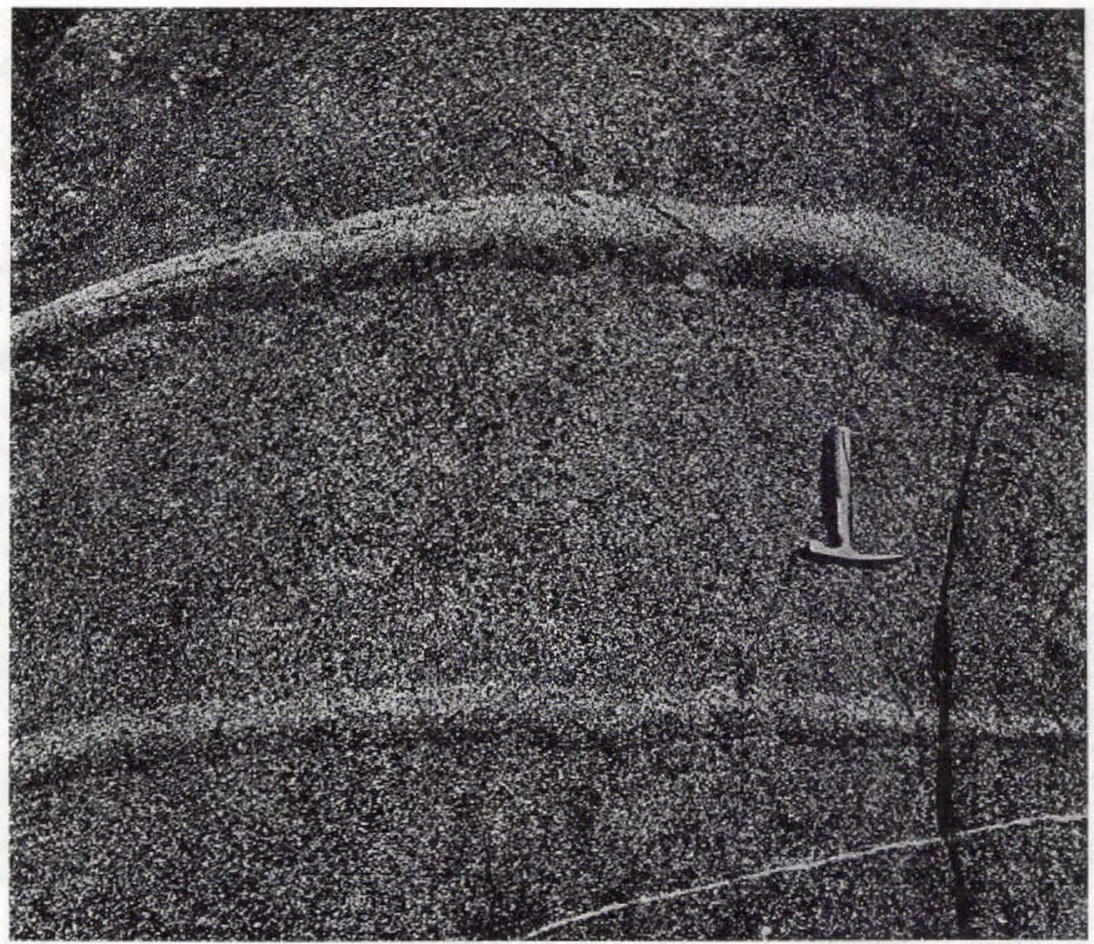

Fig. 13 Gravity-stratified layering between uniform layers of metagabbro, composed of plagioclase and green hornblende. The gabbro unit of the layered series. (Location: the summit crag of Majorqap qâva).

relict plagioclase primocrysts and is locally the dominant mafic mineral. In some places these mafic minerals occur as discontinuous primary layers.

The metagabbros typically contain $50 \%$ by volume of mafic minerals and invariably possess a relict sub-ophitic texture with mafic clots up to 5 millimetres in diameter. In the field they appear to have been completely recrystallised and are generally composed of plagioclase and hornblende. With decrease in feldspar content, these rocks pass gradationally through mela-gabbros into layers of mafitite composed of either hornblende, hornblende and pyroxene or pyroxene and olivine, with various amounts of opaque minerals and green spinel. The metagabbros possess fine examples of gravity-stratified layering (fig. 13) which resembles that described from the Tertiary Skaergaard Intrusion of East Greenland by Wager \& Deer (1939, plate 8), with thin gravity-stratified units typically between 10-15 centimetres thick, spaced at intervals of generally 50-100 centimetres between uniform layers. Rhythmic layering in which leuco-gabbro is overlain with a sharp contact by a mafitite layer 1-3 metres thick, which passes gradationally upwards with increase in total feldspar content into gabbro and then into leuco-gabbro 


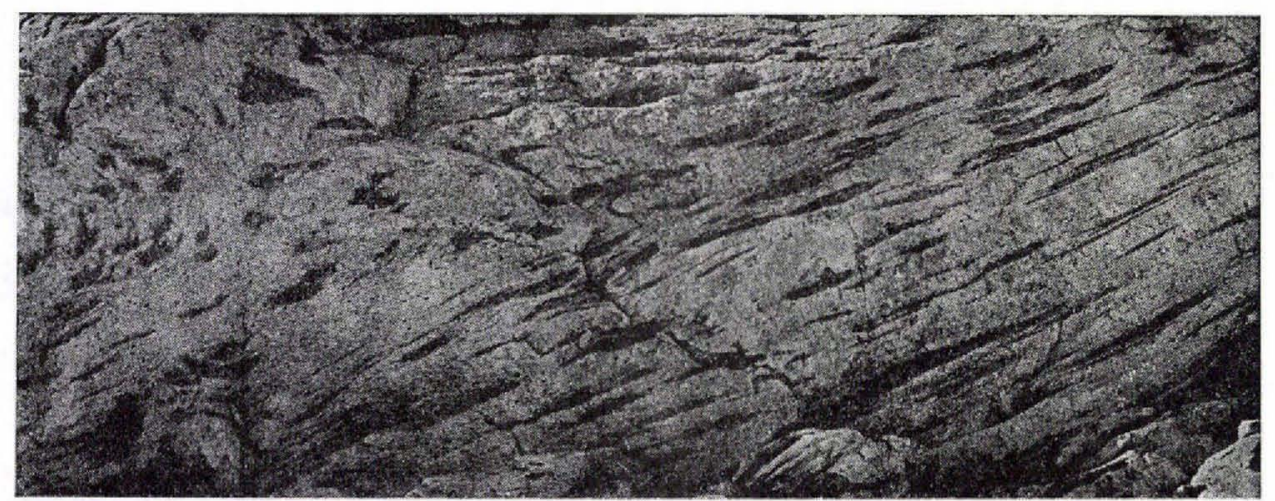

Fig. 14 Strongly deformed meta-anorthosite with flattened ellipsoidal leucogabbro schlieren (right and centre) passing (left) into irregular shaped, little deformed, leucogabbro fragments in the neutral zone of a tight fold. Anorthosite unit.

provides a second primary way-up structure. In many places there is a gradation within the mafitite layers themselves from olivine+ pyroxene-rich lower portions upwards into pyroxene + hornblende, hornblende-rich upper portions.

The top of the upper leuco-gabbro unit has not yet been identified. A major sheet of metamorphosed acid rocks, the Kûgssuatsiaup qôrua complex, occurs apparently within the upper part of this unit. It is made up of three successive intrusive units of homogeneous granitic rocks which, where least deformed, all show intrusive relationships into the leuco-gabbros but their primary age relationship with the layered series is not clear. They are different from the pegmatiteand biotite-banded Kangeq gneisses which lie beneath the layered series and which may be partly of supracrustal origin and appear to be older than the layered series.

The second main component of the Majorqap qâva outcrop is the anorthosite unit which occurs within the upper leuco-gabbro unit of the layered series as a concordant sheet up to 600 metres thick (plate 2). Generally the anorthosite unit has been more strongly deformed than the rocks of the layered series and has a post-tectonic, coarse-grained, equigranular polygonal texture with a grain size of 1-2 millimetres and does not appear to preserve an igneous texture. It contains scattered large plagioclase crystals which appear to pre-date the metamorphic texture and may be relics of a primary coarser grain size. The anorthosite unit generally contains schlieren of either leuco-gabbro (fig. 14) consisting of equigranular hornblende-plagioclase aggregates or a smaller number of garnetplagioclase aggregates, all of similar grain size and texture as the anorthosite in which they lie. In a few places where these schlieren can be traced into an area of low deformation, it is seen that the schlieren originally had a subspherical form with an irregular stellate outline and occurred with irregular di- 


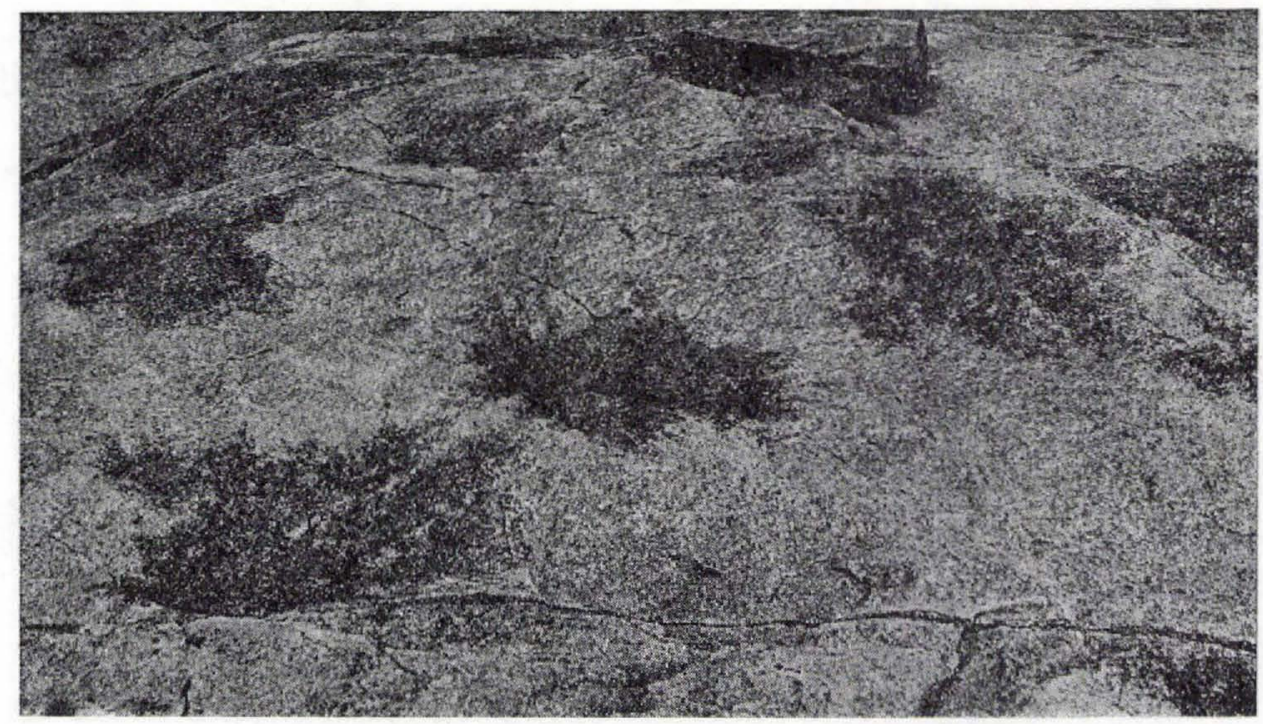

Fig. 15 Little deformed meta-anorthosite with irregularly distributed leucogabbro xenoliths with irregular stellate outlines. The undeformed appearance of the widespread leucogabbro schlieren of the anorthosite. Anorthosite unit.

stribution in the anorthosite (fig. 15). Therefore they appear to have originated as irregular-shaped xenoliths or as nucleation points of mafic minerals.

In general, the contacts of the anorthosite unit are deformed and are parallel both with its main foliation shown by the orientation of schlieren and with the main foliation and layering of the layered series. In a few localities where underformed contact relationships can be observed, veins and sheets of anorthosite cut across the igneous textures, primary rhythmic and gravity-stratified layering and a folded tectonic foliation of the rocks of the layered series. For this reason, together with the observation that the undeformed and probably primary nature of the anorthosite unit appears to have been different - in its content of irregularly distributed inclusions - from the cumulate-textured rocks of the layered series, the anorthosite unit forms a distinct structural unit of the Majorqap qâva outcrop. It may represent either a sill-like intrusion, younger than the layered series, or a primary unit of the layered series which has been partly remelted after at least two episodes of deformation of the layered series.

The anorthosite unit contains many discontinuous strips of leuco-gabbro and mafitite which are concordant with its main tectonic foliation and contacts. The mafitites are generally olive-green spinel bearing hornblendite and resemble rocks which occur as thin dykes in the undeformed parts of the layered series, cutting across the primary layering. Many of the leuco-gabbro strips contain chromitite with hornblende and biotite. It is not clear whether they originated as primary 
accumulative layers within the anorthosite, as xenolithic screens stoped from the layered series, or as intrusive sheets.

\section{References}

Berthelsen, A. 1957: The structural evolution of an ultra- and polymetamorphic gneisscomplex, West Greenland. Geol. Rdsch. 46, 173-185.

Ghisler, M. 1970: Pre-metamorphic folded chromite deposits of stratiform type in the Early Precambrian of West Greenland. Mineral Deposita 5, 223-236.

Ghisler, M. \& Windley, B. F. 1967: The chromite deposits of the Fiskenæsset region, West Greenland. Rapp. Grønlands geol. Unders. 12.

Streckeisen, A. L. 1967: Classification and nomenclature of igneous rocks. Neues Jb. Miner., Abh. 107, 144-240.

Wager, L. R. \& Deer, W. A. 1939: Geological investigations in East Greenland. Part III. The petrology of the Skaergaard Intrusion, Kangerdlugssuaq, East Greenland. Meddr Grønland $105,4$.

Windley, B. F. 1971: The stratigraphy of the Fiskenæsset Anorthosite Complex. Rapp. Grønlands geol. Unders. 35, 19-21.

Windley, B. F., Herd, R. K. \& Bowden, A. A. in press: The Fiskenæsset complex, West Greenland. Part I. A preliminary study of the stratigraphy, petrology and whole-rock chemistry. Bull. Grønlands geol. Unders. 